\title{
Determination of Heterotic Groups in Nepalese Yellow Maize Populations
}

\author{
Dil Bahadur Gurung ${ }^{1}$, Maria Luz C. George ${ }^{2}$ and Quirino D. Delacruz ${ }^{3}$ \\ ${ }^{1}$ Nepal Agricultural Research Council, National Maize Research Program, Rampur, Nepal \\ ${ }^{2}$ International Coconut Genetic Resources Network, Biodiversity International Regional Office for \\ Asia, the Pacific and Oceania, Malaysia \\ ${ }^{3}$ Central Luzon State University, Munoz, Nueva Ecija, Philippines
}

\begin{abstract}
Assigning germplasms into different heterotic groups is fundamental for exploitation of heterosis for hybrid development. An experiment was conducted in order to establish heterotic groups of some maize populations. Line $\mathrm{x}$ tester design was used for making crosses. Ten open pollinated varieties were used as lines and four as testers. Forty crosses along with their parents were evaluated in a randomized complete block design with three replications. Three testers were open pollinated varieties and one tester was a NML-2, an inbred line developed by CIMMYT. Basis of grouping the germplasms into different heterotic groups was specific combining ability (SCA) effects for grain yield.

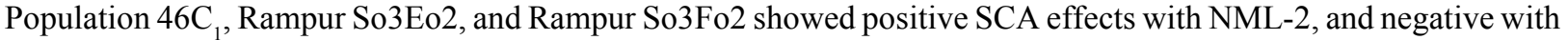
Arun-4. These germplasms were assigned into heterotic group A. Similarly, Upahar, Across 9331, Population $35 \mathrm{C}_{5}$ and Narayani had positive SCA effects with Arun-4 and negative with NML-2 and grouped into heterotic group B. Likewise, Manakamana-2 and Hill Pool Yellow were placed into AB heterotic group, which displayed positive SCA effects with both testers. Khumal yellow had shown negative effects with both testers and put into undetermined group. This way, three heterotic groups were established based on the SCA effects. These heterotic groups are potential sources for inbred line development.
\end{abstract}

Keywords: lines, testers, heterotic effects, specific combining ability effects, heterotic groupings

\section{Introduction}

Information on heterotic groupings of maize germplasm is essential for hybrid breeding program. Assigning germplasms into different heterotic groups is fundamental for the maximum exploitation of heterosis for hybrid cultivar development. Similarly, information on genetic diversity is also very important for hybrid breeding and population improvement programs for assessing the level of genetic diversity, characterizing the germplasm and assigning them into different heterotic groups (Reif et al. 2003). In hybrid maize breeding, information on genetic diversity and heterotic groups is very useful in inbred line development and evaluation for planning crosses for hybrid cultivar development. The classification of elite germplasm and inbred lines into different heterotic groups is an important task in any breeding program (Hallauer et al. 1998). Heterotic group comprises a set of genotypes that perform well when crossed with genotypes from a different heterotic group. The choice of heterotic groups is fundamental because heterotic groups and heterotic patterns are important tools for exploiting heterosis of the trait of interest.

Maize is primarily used for human consumption in Nepal. However, its demand for poultry and livestock feeds has been increasing in the areas where the poultry industries are rapidly expanding. The productivity of maize in Nepal is still very low (2.2 $\mathrm{t} /$ ha) and thus need to be increased. The increased productivity should come from the cultivation of high yielding hybrids, which is one of the viable options for increasing production and productivity of maize in Nepal. In this context, there is a need to generate information on heterosis and on specific combining ability effects of some Nepalese yellow maize 
populations for systematic hybrid breeding program. Once the heterotic groups are established based on the SCA effects for grain yield and other quantitative traits, inbred lines are developed from these heterotic groups and high yielding maize hybrids could be developed from the inbred lines.

Inbred line and hybrid development was not very systematic at the Maize Research Program in Nepal in the past. Information on heterotic groups of Nepalese open pollinated varieties is not yet available. One of the reasons might be due to the limited information generated on genetic diversity and heterotic groupings of the Nepalese maize germplasm. This study was therefore undertaken to establish the heterotic groupings based on SCA effects for grain yield and to estimate general and specific combining ability of parents used in this experiment.

\section{Materials and Methods}

A total of 14 Nepalese maize germplasm were included in this study (Table 1). Seeds of these germplasms were obtained from the National Maize Research Program (NMRP), Rampur, Nepal. Detailed description of these germplasms is presented in Table 1. Field experiments were conducted from February to September 2005 at the Fruits and Vegetables Seed Center (FVSC) of the Central Luzon State University $\left(15^{0} 43^{\mathrm{N}}\right.$ Latitude, $12^{0} 54^{\mathrm{E}} 30 \mathrm{~m}$ above msl) Science City of Munoz, Nueva Ecija, Philippines.

Table 1. Description of germplasms used as testers and lines in the field experiment

\begin{tabular}{|c|c|c|c|}
\hline Tester & $\begin{array}{l}\text { Variety/ } \\
\text { germplasm }\end{array}$ & Parentage & Germplasm description \\
\hline $\mathrm{T} 1$ & Arun-4 & $\begin{array}{l}\text { Formed using the introduced } \\
\text { germplasm and local landraces }\end{array}$ & $\begin{array}{l}\text { Open pollinated variety with early maturing } \\
\text { type, yellow flint grain, type, and a promis- } \\
\text { ing pipe line experimental variety suitable } \\
\text { for Terai, Inner Terai and mid hills. }\end{array}$ \\
\hline $\mathrm{T} 2$ & Rampur Composite & Thai composite 1 x Suwan-1 & $\begin{array}{l}\text { Yellow flint, open pollinated and full sea- } \\
\text { son variety released in } 1975 \text { for Terai envi- } \\
\text { ronments. }\end{array}$ \\
\hline T3 & NML-2 (CML-430) & AMATLC0HS169-1-1-1-1-2-2-1B*3 & $\begin{array}{l}\text { Inbred line, yellow flint grain type, and tall } \\
\text { plant type with long maturity. }\end{array}$ \\
\hline $\mathrm{T} 4$ & Pool 17E & $\begin{array}{l}\text { Comprised of crosses among the } \\
\text { early and late flint materials from } \\
\text { Mexico, the Caribbean, Central and } \\
\text { South America and Asia }\end{array}$ & $\begin{array}{l}\text { A pool developed by CIMMYT, undergoing } \\
\text { selection for early maturity and better plant } \\
\text { type and is suitable for foot hills and Terai. } \\
\text { This pool is being improved for tolerance to } \\
\text { high plant density and stalk rot. }\end{array}$ \\
\hline $\mathrm{L} 1$ & Population $46 \mathrm{C}_{1}$ & $\begin{array}{l}\text { Formed using } 240 \text { half sibs families } \\
\text { from Pool } 29 \text { C4 }\end{array}$ & $\begin{array}{l}\text { Population developed by CIMMYT, a sub- } \\
\text { tropical/temperate material, early maturing, } \\
\text { and yellow flint grains with excellent plant } \\
\text { type. A broad genetic base. Improved for } \\
\text { resistance to E. turcicum, P. sorghi and root } \\
\text { and stalk lodging. }\end{array}$ \\
\hline $\mathrm{L} 2$ & Manakamana-2 & $\begin{array}{l}\text { Formed using elite introduced } \\
\text { germplasm and local landraces. }\end{array}$ & $\begin{array}{l}\text { Open pollinated promising pipeline variety, } \\
\text { flint grain type, and long intermediate matu- } \\
\text { rity suitable for mid hills. }\end{array}$ \\
\hline $\mathrm{L} 3$ & Rampur So3Eo2 & - & $\begin{array}{l}\text { Synthetic, yellow flint grain, and interme- } \\
\text { diate maturity suitable for Terai and inner } \\
\text { Terai environments. }\end{array}$ \\
\hline
\end{tabular}




\begin{tabular}{|c|c|c|c|}
\hline L4 & Population $35 \mathrm{C}_{5}$ & $\begin{array}{l}\text { Formed using Tuxperilo, Cuba flint, } \\
\text { ETO Amarillo and } 15 \text { families from } \\
\text { the tropical late yellow flint Pool } \\
\text { ( Pool 25) }\end{array}$ & $\begin{array}{l}\text { Population developed by CIMMYT, yellow } \\
\text { dent grain type, and intermediate maturity. } \\
\text { short plant type, tolerant to most foliar } \\
\text { diseases. }\end{array}$ \\
\hline L5 & Narayani & Formed using Terai Pool yellow & $\begin{array}{l}\text { Open pollinated variety, yellow flint grain, } \\
\text { intermediate maturity and a promising pipe- } \\
\text { line genotype for Terai and Inner Terai en- } \\
\text { vironments. }\end{array}$ \\
\hline L6 & Hill Pool Yellow & $\begin{array}{l}\text { Formed using } 13 \text { varieties and } 2 \\
\text { local landraces. }\end{array}$ & $\begin{array}{l}\text { Yellow flint grain, full season and a promis- } \\
\text { ing pipeline pool suitable for mid hills and } \\
\text { high hills. }\end{array}$ \\
\hline L7 & Across 9331 & - & $\begin{array}{l}\text { Open pollinated promising pipe line variety } \\
\text { with yellow grain type and full season matu- } \\
\text { rity suitable for Terai, Inners Terai and mid } \\
\text { hills. }\end{array}$ \\
\hline L8 & Khumal Yellow & Antigua $\mathrm{G}_{2} \mathrm{D} \times$ Guatemala & $\begin{array}{l}\text { Yellow flint, tall plant type, full season open } \\
\text { pollinated variety released in } 1965 \text { for mid } \\
\text { hill environments. }\end{array}$ \\
\hline L9 & Upahar & - & $\begin{array}{l}\text { Yellow flint, intermediate maturity and open } \\
\text { pollinated promising pipeline variety suitable } \\
\text { for Terai and Inner Terai environments }\end{array}$ \\
\hline L10 & Rampur $\mathrm{So}_{3} \mathrm{Fo}_{2}$ & $\begin{array}{l}\text { Formed from the introgression of } \\
\text { NML-1, NML-2, CA00314, } \\
\text { CA00316, CA00326, CA34514, } \\
\text { CML413, and CA00108 }\end{array}$ & $\begin{array}{l}\text { Yellow flint, full season maturity and a prom- } \\
\text { ising synthetic variety suitable for Terai, } \\
\text { Inner Terai and mid hills. }\end{array}$ \\
\hline
\end{tabular}

\section{Production of Crosses}

A hybridization block was prepared at FVSC of CLSU, Philippines. Four varieties were used as testers (males) while 10 varieties were used as lines (females). Line $\mathrm{x}$ tester mating design was followed for making cross combinations. Forty crosses were made in total
(Table 2). Staggered plantings were done for males in order to ensure synchronized flowering between lines and testers. Seeds were planted in two rows of $5 \mathrm{~m}$ length in case of testers and 4 rows of $5 \mathrm{~m}$ length spaced $75 \mathrm{~cm}$ apart in case of female lines. Two seeds per hill were planted with $25 \mathrm{~cm}$ spacing between plants.

Table 2. Crosses made using 10 females and 4 males in line $\mathrm{x}$ tester mating design

\begin{tabular}{|c|c|c|c|c|}
\hline Lines ( females) & & & rs (males) & \\
\hline & $\begin{array}{l}\text { Arun-4 } \\
\text { (T1) }\end{array}$ & $\begin{array}{l}\text { NML-2 } \\
\text { (T2) }\end{array}$ & $\begin{array}{l}\text { Rampur Composite } \\
\text { (T3) }\end{array}$ & $\begin{array}{l}\text { Pool 17E } \\
\text { (T4) }\end{array}$ \\
\hline Population $46 \mathrm{C}, \mathrm{L} 1$ & L1 $\times$ T1 & L1 x T2 & L1 x T3 & L1 x T4 \\
\hline Manakamana-2 L2 & $\mathrm{L} 2 \times \mathrm{T} 1$ & $\mathrm{~L} 2 \times \mathrm{T} 2$ & L2 $\times$ T3 & L2 $\times$ T4 \\
\hline Rampur $\mathrm{So}_{2} \mathrm{EO}_{2} \mathrm{~L} 3$ & L3 x T1 & L3 x T2 & L3 $\times$ T3 & L3 x T4 \\
\hline Population $35 \mathrm{C}_{5}$ L4 & L4 x T1 & L4 x T2 & L4 x T3 & L4 x T4 \\
\hline Narayani & L5 x T1 & L5 $\times$ T2 & L5 x T3 & L5 x T4 \\
\hline Hill Pool Yellow L6 & L6 x T1 & L6 x T2 & L6 x T3 & L6 x T4 \\
\hline Across 9331 L7 & L7 x T1 & L7 x T2 & L7 x T3 & L7 x T4 \\
\hline Khumal Yellow L8 & L8 x T1 & L8 x T2 & L8 x T3 & L9 $\times$ T4 \\
\hline Upahar & L9 $\times$ T1 & L9 $x$ T2 & L9 x T3 & L9 $\times$ T4 \\
\hline Rampur $\mathrm{So}_{2} \mathrm{Fo}_{2} \mathrm{~L} 10$ & $\mathrm{~L} 10 \times \mathrm{T} 1$ & L10 x T2 & L10 x T3 & L10 x T4 \\
\hline Number of crosses & 10 & 10 & 10 & 10 \\
\hline Total number of crosses & 40 & & & \\
\hline
\end{tabular}

$\mathrm{T}_{1}-\mathrm{T}_{4}$ : tester 1 to tester $4, \mathrm{~L}_{1}-\mathrm{L}_{10}$ : line 1 to Line 10 
Fertilizers were applied at the rate of 120: 60: 40 NPK kg /ha. All of $\mathrm{P}_{2} \mathrm{O}_{5}$ and $\mathrm{K}_{2} \mathrm{O}$ and half of Nitrogen were applied at the time of planting. The remaining half of Nitrogen was applied 45 days after planting. Weeding was done two weeks after planting whereas hilling up was done 45 days after planting. Experimental plots were irrigated weekly. Furadon $3 \mathrm{G}$ was applied in the whorl of leaves at $0.5 \mathrm{~kg}$ a.i. ha $^{-1}$ to control corn borer (Chilo partellus) . Similarly, Sevin was also sprayed @ of 2 g / 1 of water to control the earworm before and after pollination. Ears were covered with silk bags before the emergence of silk in female lines. Bagging of silk in female ears was done in morning and in late afternoon everyday. Similarly, tassels of testers were bagged in late afternoon to avoid contamination of the pollens. On the following morning, pollen grains were collected from each covered tassel of a particular tester. Pollens were bulked in a tassel bag and then bulked pollen was poured over the silks of female plants. Pollinated ears were covered again with tassel bags to prevent cross pollination. Pollination was performed everyday from $8 \mathrm{o}^{\prime}$ clock in the morning to $2 \mathrm{o}^{\prime}$ clock in the afternoon. Seven plants were pollinated for each cross combination to get sufficient seeds for hybrid evaluation. The matured ears of each cross were harvested separately. The harvested ears were shelled, and dried separately. The seeds were then kept separately in the seed storage for the wet season evaluation.

\section{Evaluation of Hybrids}

Forty crosses along with their parents were evaluated at the FVSC of the CLSU, Philippines. A randomized complete block design with three replications was used for evaluation of the crosses and their parents. Seeds were planted in two rows of 4 meter length. Two seeds per hill were planted $25 \mathrm{~cm}$ apart between hills and $75 \mathrm{~cm}$ spaced between rows. Plant population was maintained at $53500 /$ ha after thinning.

Fertilizers were used @120:60:40 NPK kg/ha.All of $\mathrm{K}_{2} \mathrm{O}, \mathrm{P}_{2} \mathrm{O}_{5}$, and half dose of Nitrogen were applied at the time of planting. Remaining half dose of Nitrogen was applied 45 days after planting. Weeding operation was done two weeks after planting. Hilling up was done twice; first after 30 days and the second, after silk emergence. All standard crop management practices were followed during the whole experimental period. Furadon $3 \mathrm{G}$ was applied in the whorl of the leaves at the rate of 0.5 a.i. ha ${ }^{-1}$ to control the corn borer. Harvesting was done depending upon the maturity of the whole plot basis. Ears from each plot were harvested. Grain yield was taken on the plot yield basis. Observations were taken for days to $50 \%$ silking, plant height, ear height ear length, number of kernels per ear, 100 seed weight and grain yield.

Step by step procedure as suggested by Singh and Chaudhary (1977) was followed for the line $\mathrm{x}$ tester analysis. Analysis of variance, general combining ability (GCA) and specific combining ability (SCA) effects for grain yield and other quantitative traits were analyzed on the line $\mathrm{x}$ tester model. Test of significance for GCA and SCA effects were done against the Student's t-test with error degree of freedom. Heterosis over mid parents was calculated and estimated. All these statistical analyses were verified by analyzing these data again in the SAS line $\mathrm{x}$ tester windows based computer program. Mean squares of the mid parent heterosis were tested against the error variance by the usual "F"-test.

\section{Results and Discussion}

Results of the analysis of variance in 40 crosses and 14 parents for yield and yield component traits have been presented in Table 4 . The analysis of variance for yield and other quantitative traits showed highly significant differences among parents, crosses, parents versus hybrids and lines for all traits studied except for plant height and ear length in parents versus hybrids (Table 3 ). Similarly, highly significant differences were observed in Line $\mathrm{x}$ Tester for grain yield, days to $50 \%$ silking, ear height, and ear length except for plant height, number of kernels and 100 seed weight. The result revealed that there were significant differences for all traits under investigation indicating the presence of dominance effects. 
Table 3. Analysis of variance for yield and yield component traits

\begin{tabular}{|c|c|c|c|c|c|c|c|c|}
\hline \multicolumn{9}{|l|}{ Mean Squares } \\
\hline SV & $\mathrm{DF}$ & $\begin{array}{l}\text { Days to } 50 \% \\
\text { silking }\end{array}$ & $\begin{array}{l}\text { Plant } \\
\text { height } \\
(\mathrm{cm})\end{array}$ & $\begin{array}{l}\text { Ear height } \\
(\mathrm{cm})\end{array}$ & $\begin{array}{l}\text { Ear length } \\
(\mathrm{cm})\end{array}$ & $\begin{array}{l}\text { Number of } \\
\text { kernels/ear }\end{array}$ & $\begin{array}{l}100 \text { seed } \\
\text { weight }(\mathrm{g})\end{array}$ & $\begin{array}{l}\text { Grain yield } \\
(\mathrm{kg} / \mathrm{ha})\end{array}$ \\
\hline Treatments & 53 & $46.89 * *$ & $476.94 * *$ & $677.08 * *$ & $2.36 * *$ & $3941.22 * *$ & $11.02 * *$ & $3468446.27 * *$ \\
\hline Parents & 13 & $96.09 * *$ & $789.36^{* *}$ & $966.17 * *$ & $3.13 * *$ & $4626.58 * *$ & $11.63 * *$ & $3426735.00 * *$ \\
\hline Parents vs. Crosses & 1 & $109.65 * *$ & $731.23 \mathrm{~ns}$ & $2388.56 * *$ & $2.49 \mathrm{~ns}$ & $15136.59^{* *}$ & $33.19 * *$ & $1450978.47 * *$ \\
\hline Crosses & 39 & $28.88 * *$ & $366.28 * *$ & $536.82 * *$ & $2.09 * *$ & $3425.70 * *$ & $10.25^{* *}$ & $3199238.89 * *$ \\
\hline Line & 9 & $33.39 * *$ & $648.80 * *$ & $646.50 * *$ & $2.94 * *$ & $5375.96 * *$ & $12.40 * *$ & $1984474.17 * *$ \\
\hline Testers & 3 & $204.91 * *$ & $1207.37 * *$ & $2104.17 * *$ & $1.10 \mathrm{~ns}$ & $7214.94 * *$ & $62.64 * *$ & $5361423.86^{* *}$ \\
\hline Line $\mathrm{x}$ Tester & 27 & $7.81 * *$ & $178.65 \mathrm{~ns}$ & $326.12 * *$ & $1.92 *$ & $2354.58 \mathrm{~ns}$ & $3.70 \mathrm{~ns}$ & $3363917.70 * *$ \\
\hline Error & 106 & 3.79 & 160.3 & 175.16 & 1.14 & 1714.91 & 4.05 & 318187.8 \\
\hline
\end{tabular}

*Significant at 5\%level; $\quad * *$ Significant at $1 \%$ level; $\quad \mathrm{ns}=$ non significant

The highly significant of SCA effects was observed in Rampur So3Fo2 /NML-2 for days to $50 \%$ silking while Population $46 \mathrm{C}_{1} /$ Pool 17E showed the highest significant negative SCA effect. Crosses with negative SCA effects could be utilized for developing early maturing hybrids (Table-4). Koirala and Gurung (2002) found the SCA effects ranging from -1.35 to 1.18 in seven yellow Nepalese maize populations. The negative SCA effects were also reported by Vasal et al. (1992) in CIMMYT's tropical x subtropical maize germplasms and by Mungoma et al (1988) and in ten corn belt exotic germplasms.

Rampur So3Fo2/NML-2 was a best combiner among the crosses in terms of plant height. Since tall plants are not considered desirable. Parents of the crosses showing negative SCA effects could be utilized in reducing plant height in hybrids. Vasal et al. (1993) reported significant SCA effects for plant height in CIMMYT's quality protein maize germplasm. The result obtained by Koirala and Gurung (2002a, 2002b) was similar in seven yellow maize populations. The SCA effects for plant height ranged from -8.74 to 7.98 in these germplasms.

Similarly, Khumal Yellow/ Pool 17E had highly significant SCA effects for ear height. Hill Pool Yellow/ NML-2 and Hill Pool Yellow/Arun-4 had shown significant SCA effects for ear length. With respect to number of kernels per ear, Population $46 \mathrm{C}_{1} /$ Rampur Composite showed the highly significant SCA effects. The SCA effects for 100 seed weight were significant in Rampur So3Fo2/NML-2 (Table 4).

Table 4. Specific combining of yield and yield contributing traits

\begin{tabular}{|c|c|c|c|c|c|c|c|c|}
\hline Lines & Testers & $\begin{array}{l}\text { Days } \\
50 \% \\
\text { silking }\end{array}$ & \begin{tabular}{l|l} 
to & Plant height \\
$(\mathrm{cm})$
\end{tabular} & $\begin{array}{l}\text { Ear height } \\
(\mathrm{cm})\end{array}$ & $\begin{array}{l}\text { Ear length } \\
(\mathrm{cm})\end{array}$ & $\begin{array}{l}\text { No of } \\
\text { kernels/ } \\
\text { ear }\end{array}$ & $\begin{array}{l}100 \text { seed } \\
\text { weight } \\
(\mathrm{g})\end{array}$ & $\begin{array}{l}\text { Grain } \\
\text { yield (kg/ } \\
\text { ha) }\end{array}$ \\
\hline & & SCA & SCA & SCA & SCA & SCA & SCA & SCA \\
\hline $\begin{array}{l}\text { Population } \\
46 \mathrm{C}_{1}\end{array}$ & $\begin{array}{l}\text { Arun-4 } \\
\text { Rampur Composite } \\
\text { NML-2 } \\
\text { Pool 17E }\end{array}$ & $\begin{array}{l}3.34 \\
0.74 \\
-0.25 \\
-3.82\end{array}$ & $\begin{array}{l}1.98 \\
7.19 \\
0.40 \\
-9.58\end{array}$ & $\begin{array}{l}9.80 \\
0.54 \\
-1.33 \\
-9.02\end{array}$ & $\begin{array}{l}-1.21 \\
-1.04 \\
-0.96 \\
-0.82\end{array}$ & $\begin{array}{l}-37.25 \\
64.23 \\
17.14 \\
-44.13\end{array}$ & $\begin{array}{l}-1.47 \\
0.99 \\
0.83 \\
-0.35\end{array}$ & $\begin{array}{l}-1967.98 \\
1740.52 \\
1213.27 \\
-985.81\end{array}$ \\
\hline Manakamana-2 & $\begin{array}{l}\text { Arun-4 } \\
\text { Rampur Composite } \\
\text { NML-2 } \\
\text { Pool 17E }\end{array}$ & $\begin{array}{l}-0.49 \\
-0.42 \\
0.24 \\
0.67\end{array}$ & $\begin{array}{l}6.43 \\
2.04 \\
-12.00 \\
4.067\end{array}$ & $\begin{array}{l}4.95 \\
5.89 \\
-11.24 \\
0.39\end{array}$ & $\begin{array}{l}-0.77 \\
-0.73 \\
-0.69 \\
-0.55\end{array}$ & $\begin{array}{l}3.39 \\
9.74 \\
-7.54 \\
-5.58\end{array}$ & $\begin{array}{l}0.22 \\
1.56 \\
-2.23 \\
0.44\end{array}$ & $\begin{array}{l}548.94 \\
-630.42 \\
1022.60 \\
-941.12\end{array}$ \\
\hline Rampur $\mathrm{So}_{3} \mathrm{Eo}_{2}$ & \begin{tabular}{l|} 
Arun-4 \\
Rampur Composite \\
NML-2 \\
Pool 17E
\end{tabular} & $\begin{array}{l}0.92 \\
-0.01 \\
-1.01 \\
0.09\end{array}$ & $\begin{array}{l}-1.31 \\
14.49 \\
-3.16 \\
-10.01\end{array}$ & $\begin{array}{l}5.34 \\
9.81 \\
-4.66 \\
-10.49\end{array}$ & $\begin{array}{l}-0.53 \\
-0.49 \\
-0.43 \\
-0.42\end{array}$ & $\begin{array}{l}4.47 \\
-7.70 \\
-5.39 \\
8.62\end{array}$ & $\begin{array}{l}0.38 \\
0.15 \\
0.73 \\
-1.27\end{array}$ & $\begin{array}{l}-1047.88 \\
70.90 \\
1182.91 \\
-205.93\end{array}$ \\
\hline Population $35 \mathrm{C}_{5}$ & $\begin{array}{l}\text { Arun-4 } \\
\text { Rampur Composite } \\
\text { NML-2 } \\
\text { Pool 17E }\end{array}$ & $\begin{array}{l}-0.15 \\
-1.75 \\
1.24 \\
0.67\end{array}$ & $\begin{array}{l}1.60 \\
-1.25 \\
2.08 \\
-2.43\end{array}$ & $\begin{array}{l}-4.49 \\
-4.28 \\
16.56 \\
-7.79\end{array}$ & $\begin{array}{l}-0.39 \\
-0.31 \\
-0.21 \\
-0.20\end{array}$ & $\begin{array}{l}25.94 \\
-32.22 \\
33.40 \\
-27.13\end{array}$ & $\begin{array}{l}1.76 \\
-0.79 \\
0.41 \\
-1.39\end{array}$ & $\begin{array}{l}647.16 \\
166.13 \\
-676.80 \\
-136.49\end{array}$ \\
\hline
\end{tabular}


Nepal Journal of Science and Technology 10 (2009) 1-8

\begin{tabular}{|c|c|c|c|c|c|c|c|c|}
\hline Narayani & $\begin{array}{l}\text { Arun-4 } \\
\text { Rampur Composite } \\
\text { NML-2 }\end{array}$ & $\begin{array}{l}-2.65 \\
1.07 \\
-0.92\end{array}$ & $\begin{array}{l}7.16 \\
-3.35 \\
0.63\end{array}$ & $\begin{array}{l}-3.05 \\
-0.31 \\
10.06\end{array}$ & $\begin{array}{l}-0.19 \\
-0.15 \\
-0.12\end{array}$ & $\begin{array}{l}21.67 \\
-7.83 \\
-1.59\end{array}$ & $\begin{array}{l}0.25 \\
-0.51 \\
-1.09\end{array}$ & $\begin{array}{l}985.64 \\
-1176.56 \\
-92.44\end{array}$ \\
\hline Hill Pool Yellow & $\begin{array}{l}\text { Pool 17E } \\
\text { Arun-4 } \\
\text { Rampur Composite } \\
\text { NML-2 }\end{array}$ & $\begin{array}{l}2.50 \\
-0.24 \\
0.49 \\
0.15\end{array}$ & $\begin{array}{l}-4.46 \\
2.23 \\
-4.95 \\
4.38\end{array}$ & $\begin{array}{l}-6.69 \\
10.64 \\
-9.68 \\
-2.63\end{array}$ & $\begin{array}{l}0.01 \\
0.06 \\
0.09 \\
0.14\end{array}$ & $\begin{array}{l}-12.23 \\
43.56 \\
-11.04 \\
-42.30\end{array}$ & $\begin{array}{l}1.34 \\
-0.59 \\
0.53 \\
0.06\end{array}$ & $\begin{array}{l}283.37 \\
287.20 \\
-67.66 \\
96.08\end{array}$ \\
\hline Lines & Testers & $\begin{array}{l}\text { Days to } \\
50 \% \\
\text { silking } \\
\text { SCA }\end{array}$ & $\begin{array}{l}\text { Plant } \\
\text { height } \\
(\mathrm{cm}) \\
\text { SCA }\end{array}$ & $\begin{array}{l}\text { Ear } \\
\text { height } \\
(\mathrm{cm}) \\
\text { SCA }\end{array}$ & $\begin{array}{l}\text { Ear length } \\
(\mathrm{cm}) \\
\text { SCA }\end{array}$ & $\begin{array}{l}\text { No of } \\
\text { kernels/ear } \\
\qquad \text { SCA }\end{array}$ & $\begin{array}{l}100 \text { seed } \\
\text { weight }(\mathrm{g}) \\
\text { SCA }\end{array}$ & $\begin{array}{l}\text { Grain yield } \\
(\mathrm{kg} / \mathrm{ha}) \\
\text { SCA }\end{array}$ \\
\hline Across 9331 & $\begin{array}{l}\text { Pool 17E } \\
\text { Arun-4 } \\
\text { Rampur Composite } \\
\text { NML-2 } \\
\text { Pool 17E }\end{array}$ & $\begin{array}{l}-0.40 \\
-0.49 \\
-0.75 \\
0.90 \\
-1.42\end{array}$ & $\begin{array}{l}-1.66 \\
-4.31 \\
0.23 \\
2.83 \\
-1.17\end{array}$ & $\begin{array}{l}1.67 \\
-4.85 \\
-6.98 \\
-1.06 \\
3.54\end{array}$ & $\begin{array}{l}0.21 \\
0.22 \\
0.24 \\
0.24 \\
0.26\end{array}$ & $\begin{array}{l}9.78 \\
-14.27 \\
-9.91 \\
7.45 \\
5.88\end{array}$ & $\begin{array}{l}-0.01 \\
-0.35 \\
-0.29 \\
1.70 \\
-1.54\end{array}$ & $\begin{array}{l}-315.63 \\
563.14 \\
-264.470 \\
-807.474 \\
1118.406\end{array}$ \\
\hline Khumal Yellow & $\begin{array}{l}\text { Arun-4 } \\
\text { Rampur Composite } \\
\text { NML-2 } \\
\text { Pool 17E }\end{array}$ & $\begin{array}{l}1.34 \\
2.84 \\
-0.59 \\
-1.82\end{array}$ & $\begin{array}{l}5.81 \\
-11.60 \\
-3.43 \\
11.65\end{array}$ & $\begin{array}{l}-5.35 \\
-6.19 \\
-0.16 \\
21.07\end{array}$ & $\begin{array}{l}0.42 \\
0.43 \\
0.45 \\
0.45\end{array}$ & $\begin{array}{l}-7.32 \\
-9.906 \\
1.06 \\
17.02\end{array}$ & $\begin{array}{l}-0.54 \\
0.31 \\
-0.62 \\
1.34\end{array}$ & $\begin{array}{l}-406.93 \\
-929.18 \\
-181.47 \\
907.98\end{array}$ \\
\hline Upahar & $\begin{array}{l}\text { Arun-4 } \\
\text { Rampur Composite } \\
\text { NML-2 } \\
\text { Pool 17E }\end{array}$ & $\begin{array}{l}-1.15 \\
0.90 \\
0.90 \\
-0.65\end{array}$ & $\begin{array}{l}-11.06 \\
0.41 \\
0.68 \\
9.96\end{array}$ & $\begin{array}{l}-7.47 \\
20.39 \\
-5.88 \\
-7.04\end{array}$ & $\begin{array}{l}0.49 \\
0.55 \\
0.59 \\
0.72\end{array}$ & $\begin{array}{l}-5.35 \\
-2.13 \\
14.70 \\
-7.20\end{array}$ & $\begin{array}{l}0.68 \\
-0.52 \\
-0.27 \\
0.11\end{array}$ & $\begin{array}{l}1852.24 \\
-621.98 \\
-1187.23 \\
-43.02\end{array}$ \\
\hline Rampur $\mathrm{So}_{3} \mathrm{Fo}_{2}$ & $\begin{array}{l}\text { Arun-4 } \\
\text { Rampur Composite } \\
\text { NML-2 } \\
\text { Pool 17E }\end{array}$ & $\begin{array}{l}-0.40 \\
-1.34 \\
4.59 \\
2.42\end{array}$ & $\begin{array}{l}-8.53 \\
-0.78 \\
23.13 \\
1.23\end{array}$ & $\begin{array}{l}-5.50 \\
0.165 \\
18.49 \\
4.99\end{array}$ & $\begin{array}{l}1.08 \\
1.09 \\
1.39 \\
1.50\end{array}$ & $\begin{array}{l}-34.84 \\
7.64 \\
16.95 \\
44.11\end{array}$ & $\begin{array}{l}-0.34 \\
-0.95 \\
3.17 \\
0.83\end{array}$ & $\begin{array}{l}-1461.54 \\
1103.12 \\
195.96 \\
927.86\end{array}$ \\
\hline
\end{tabular}

Significant differences of SCA effects were observed in 10 specific cross combinations for grain yield. Upahar/Aran-4 had the highest SCA effects (Table 4). The other superior specific cross combinations were Population $46 \mathrm{C}_{1} /$ Rampur Composite, Population $46 \mathrm{C}_{1} /$ NML-2, Rampur So Eo2/NML-2, Across 9331/Pool 17E, Rampur So3Fo2/Rampur Composite, Manakamana-2/ NML-2, Narayani/Aran-4, Rampur So3Fo2/Pool 17E, Khumal Yellow /Pool 17E and Population 35C $\mathrm{C}_{5}$ /Arun-4. These crosses could be utilized for developing inbred lines. One or two outstanding crosses could recommend for cultivation after testing in farmer fields. The range of SCA effects for grain yield as reported by Onay et al. (2004) was from -217.37 to 432.15 in Turkey's maize populations. The values of the SCA effects were comparatively lower than those values obtained in this study. The values of positive and negative SCA effects as reported by Xingming et al. (2001) were slightly higher than that of the values obtained in this study. Koirala and Gurung (2002) reported similar results in seven yellow Nepalese maize populations and by Jha et al. (1991) in best performing crosses of maize inbred lines. SCA effects for grain yield of CIMMYT's subtropical and temperate early maturing maize germplasm was found significant in temperate environment and non significant in subtropical environment. Beck et al. (1991) reported significant positive SCA effects in CIMMYT's subtropical and temperate intermediate maturity maize germplasm.

A method described by Pswarayi and Vivek (2004) and Menkir et al. 2004 was followed for assigning germplasm into different heterotic groups. SCA effects for grain yield were the main basis for grouping the germplasm into different heterotic groups. Four testers were used for making crosses with ten lines. Of the four testers, two testers were only used for determining heterotic groups. One was NML-2, an inbred line developed by CIMMYT and the other was Arun-4, an open pollinated variety developed in Nepal.Germplasm showing positive SCA effects with NML-2 and exhibiting negative SCA effects with Arun-4 were assigned into heterotic group A. Germplasm showing positive SCA effects with Arun-4 and negative effects with NML-2 were grouped into heterotic group B. Similarly, germplasm showing positive SCA effects with both testers were placed under $A B$ heterotic group. Likewise, the germplasm exhibiting negative SCA effects with both testers were kept under a separate undetermined group (Table 5). Based on the SCA effects for grain yield, germplasms were classified into A, B and $\mathrm{AB}$ heterotic groups. 
Table 5. Classification of germplasm into different heterotic groups based on SCA effects for grain yield

\begin{tabular}{l|l|l|l|l|l}
\hline \multirow{2}{*}{ Lines } & \multicolumn{2}{|c|}{ Grain yield } & \multicolumn{2}{c|}{ SCA effects } & $\begin{array}{l}\text { Proposed heterotic } \\
\text { group }\end{array}$ \\
\cline { 2 - 6 } & NML-2 & Arun-4 & NML-2 & Arun-4 & \\
\hline Population 46C 1 & 8164.18 & 4217.52 & 1213.27 & -1967.98 & A \\
Rampur So3Eo2 & 8957.65 & 5961.44 & 1182.91 & -1047.88 & A \\
Rampur So3Fo2 & 6012.81 & 4458.39 & 195.96 & -1461.54 & A \\
Upahar & 5572.98 & 7847.06 & -1187.23 & 1852.24 & B \\
Across 9331 & 5352.96 & 5958.17 & -807.47 & 563.14 & B \\
Population 35C & 6012.81 & 6571.37 & -676.804 & 647.16 & B \\
Narayani & 6489.93 & 6802.61 & -92.44 & 985.64 & B \\
Manakamana-2 & 7713.14 & 6474.07 & 1022.60 & 548.94 & AB \\
Hill Pool Yellow & 6867.28 & 6292.98 & 96.08 & 287.20 & AB \\
Khumal Yellow & 6449.50 & 5458.63 & -181.47 & -406.93 & Undetermined \\
\hline
\end{tabular}

Germplasms assigned under heterotic group A were Population 46C $\mathrm{C}_{1}$, Rampur So3Eo2, and Rampur So3Fo2 while Upahar, Across 9331, Population $35 \mathrm{C}_{5}$ and Narayani were under heterotic group $\mathrm{B}$. Under the $\mathrm{AB}$ group were Manakamana-2, and Hill Pool Yellow. Khumal Yellow was kept under undetermined group (Table 5).

Zhang et al. (2005) described different methods used by maize breeders for classifying germplasm into different heterotic groups. Two groups; Reid and Lancaster were classified in the US in 1947 based on the geographical origin and pedigree of the germplasm. They further explained that germplasm could be classified into different heterotic groups based on the SCA effects for grain yield.

Similar findings on heterotic groupings were reported by Pswarayi and Vivek (2004) in 12 CIMMYT early maturing inbred lines in which they assigned the inbred lines into $\mathrm{A}, \mathrm{B}$, and $\mathrm{AB}$ heterotic groups and undetermined based on the positive and negative effects shown by the germplasm with the testers. Menkir et al. (2004) also used similar method for classifying 23 inbred lines into different heterotic groups based on SCA effects and test cross mean grain yield. They established A and $\mathrm{B}$ heterotic groups (dent and flint type) based on the lines showing either positive or negative SCA effects with the testers. Similarly, Vasal et al (1992a, 1992b) assigned 92 tropical and 88 subtropical inbred lines in to different heterotic groupings. They evaluated inbred lines using two dent and two flint testers. The lines exhibiting contrasting SCA effects with two of the four testers were grouped into a separate group. They kept the line showing negative SCA effects with both of the testers as undetermined.
Likewise, Teng and Li (2004) had categorized 84 parental lines of 71 widely used hybrids into 5 heterotic groups namely; Reid, Temp-Tropic I, Zi330, Tang SPT and Lancaster. Similarly, Xingming et al (2001) made 4 heterotic groups (A, B, C, and D from 10 QPM lines based on the SCA effects.

Based on the SCA effects for grain yield, ten yellow maize populations were established into $\mathrm{A}, \mathrm{B}$, and $\mathrm{AB}$ heterotic groups. Germplasm within the same group are genetically similar while between the two groups are dissimilar. Inbred lines could be developed from these heterotic groups. High yielding hybrids could be developed from these inbred lines. These heterotic groups could serve as sources for developing inbred line and hybrids.

Based on the SCA effects for grain yield, germplasm were classified into $\mathrm{A}, \mathrm{B}$ and $\mathrm{AB}$ heterotic groups. Germplasms under heterotic group A were Population 46C 1 , Rampur So3Eo2, and Rampur So3Fo2 while Upahar, Across 9331, Population $35 \mathrm{C}_{5}$ and Narayani were under heterotic group $\mathrm{B}$. Under the $\mathrm{AB}$ group were Manakamana-2, and Hill Pool Yellow. Khumal Yellow was kept under undetermined group. These groupings were in accordance with production environments in which germplasm were being cultivated and adapted in Nepal. These heterotic groups could serve as a guideline to the maize breeders for exploiting the maximum heterosis for hybrid variety development.

\section{Acknowledgement}

Authors are very grateful to the Nepal Agricultural Research Council and the Hill Maize Research Project 
for providing financial assistance to this study. The authors are also thankful to the National Maize Research Program, Rampur, Nepal for providing seeds of different maize germplasms for this experiment.

\section{References}

Beck, D.L., S.K. Vasal and J. Crossa.1991. Heterosis and combining ability of CIMMYT's tropical early and intermediate maturity maize germplasm. Maydica 35(3):279-285.

Gurung, D.B. and K.B. Koirala. 2002a. Maize landraces from the mid and far western hills of Nepal: An exploration and evaluation for cultivar development. In: Proceedings of a maize symposium on sustainable maize production systems for Nepal, December 3-5, 2001, Kathmandu, Nepal. (Eds. Neeranjan P. Rajbhandari, Joel K. Ransom, Krishna Adhikari and and A.F.E. Palmer). Hill Maize Research Project, Kathmandu.pp.75-81.

Gurung, D.B. and K.B. Koirala. 2002b. Characterization of maize landraces from the mid and far western hills of Nepal. Ibid. pp. 100-104.

Haullauer, A.R., W.A. Russell and K.R. Lamkey.1998. Corn breeding. In:Corn and corn improvement. 3rd edition. (Eds. G.F. sprange and J.W. Dudley) Agron. Monogr.18. Madison, WI. ASA, CSSA and SSSA, 677 South Segoe Road, Madison, WI, 53711, USA, pp. 463-564

Jha, P.B. and A.S. Khehra.1991. Evaluation of maize inbred lines derived from two heterotic populations. Indian Journal of Genetics 52(2):126-133.

Koirala, K.B. and D.B. Gurung. 2002. Heterosis and combining ability of seven yellow maize populations in Nepal. In: Proceedings of the $8^{\text {th }}$ Asian regional maize workshop held August 5-8, 2002. Bangkok, Thailand, pp. 148-155.

Menkir, A., M. Berhan, C.I. Ingelbrecht and A. Adepoju. 2004. Grouping of tropical mid altitude maize inbred lines on the basis of yield data and molecular analysis. Theoretical Applied Genetics 108:15821590.

Mungoma, C. and L.M.Pollak.1988. Heterotic patterns among ten Corn Belt and exotic maize populations. Crop Sci.28:500-504.

Ordas, A. 1991. Heterosis in crosses between American and Spanish populations of maize. Crop Science 31:931-935.

Onay, A., H. Basal and C. Conak.2004. Inheritance of grain yield in a half diallel maize germplasm. Turkish Journal of Agriculture Forum 28:239-244.
Pswarayi, A. and B. Vivek. 2004. Combining ability of CIMMYT's early maturing maize ( Zea mays L.) germplasm under stress and non stress conditions and identification of testers. Retrieved: September 12, 2005 from http: www.cropscience.org.au/icsc204/ poster/3/4/5/845_vivekb.htm.

Rief, J.C, A.E. Melchinger, X.C. Xia, M. L. Warburton, D. A. Hoisington, S.K. Vasal, G. Srinivasan, M. Bohn and M. Frisch. 2003. Genetic distance based on simple sequence repeats and heterosis in tropical maize populations. Crop science 43(4): 1275-1282.

Shing, R.K and B.D. Chaudhary.1997. Biometrical in quantitative genetic analysis .Kalyani Publishers, New Delhi, India. pp. 205-214.

Teng, W.T. and J.S. Li. 2004. Investigation of maize heterotic groups and patterns in China. Retrieved: September 15,2005 from http:/www.cropscience.org.au/icsc2004/ poster/3/4/4/1153_lijiansheng.htm.

Vasal, S. K, G. Srinivasan, F. Gonzalez, G. C. Han, S. Pandey, D.L. Beck and J. Crossa. 1993. Heterosis and combining ability of CIMMYT's tropical and subtropical germplasm. Crop Science 32:1477-1483.

Vasal, S.K., G. Srinivasan, F. Gonzalez, G.C. Han, S. Pandey, D.L. Beck and J. Crossa.1993. Heterosis and combining ability of CIMMYT's quality protein maize germplasm. Crop Science 33:51-57.

Vasal, S.K., G. Srinivasan, F. Gonzalez, G.C. Han, S. Pandey, D.L. Beck and J. Crossa.1992. Heterosis and combining ability of CIMMYT's subtropical and temperate early - maturity maize germplasm. Crop Science 32:884-890.

Vasal, S.K., G. Srinivasan, J. Crossa and D.L. Beck and J. Crossa.1992b. Heterosis and combining ability of CIMMYT's subtropical and temperate early maize germplasm. Crop Science 32:884-890.

Vasal, SK, G. Srinivasan, J. Crossa, D.L. Beck, S. Pandey, and C. De Leon 1992a. Heterosis and combining ability of CIMMYT's subtropical and temperate early - maturity maize germplasm. Maydica.37:217223.

Warburton, M.L., X. Xianchun, J. Crossa, J. Franco, A.E., Yuan, L.X., J.H. Fu, S.H.

Xingming, F., T.J. Huang Bihua and L. Feng .2001. An analysis of combining ability of and heterotic groups of yellow grain quality protein maize inbred lines. In. Proceedings of the seventh eastern and southern Africa regional maize workshop. pp. 143-148.

Zhang, S., Z. Peng, L. Yuan and X. Li. 2005. Heterotic pattern and germplasm enhancement in maize breeding in China. Retrieved: September 10, 2005 from http:/ www. Chinamaize.com.cn/kjjz/kylw/hylw/lw19.html. 